\title{
RASIONALITAS KONSUMSI PETANI MUSLIM PADA DESA SUMBER KABUPATEN PROBOLINGGO DALAM PERSPEKTIF ISLAM ${ }^{\prime \prime}$
}

\author{
M. Alvian Arfiliananda \\ Mahasiswa Program Studi S1 Ekonomi Islam Fakultas Ekonomi dan Bisnis Universitas Airlangga \\ Email: m.alvian.a-11@feb.unair.ac.id \\ Atina Shofawati \\ Departemen Ekonomi Syariah Fakultas Ekonomi dan Bisnis Universitas Airlangga \\ Email: atina-o@feb.unair.ac.id
}

\begin{abstract}
The aim of the study is to know the Consumption Rationality of Moslem Farmer in Sumber Village, Probolinggo District in Islamic perspective. The method used case study with qualitative descriptive approach. This study is using interview for primary data. This study scope focus is limited to moslem farmer in Sumber Village. Probolinggo District who has their own farmland. In this study, consumption preference theory in Islam is used as a scope to search answers on how is the rationality consumption of moslem farmer in sumber village Probolinggo District in Islamic perspective.

The results obtained were how Moslem Farmer in Sumber Village, Probolinggo District consumption is in accordance with the consumption rationality in Islam. It is proven by the balance between mundane (duniawi) consumption with the afterlife, and how the necessity fulfilled suits consumption principal in Islam.
\end{abstract}

\section{Keywords: Consumption Rationality in Islam, Moslem Farmer}

\section{PENDAHULUAN}

Manusia pada hakekatnya dituntut untuk bekerja dan berusaha untuk memenuhi kebutuhan hidupnya. Mereka memiliki berbagai macam kebutuhan dalam hidupnya yaitu kebutuhan jasmani dan rohani. Semua kebutuhan itu diperlukan oleh semua umat manusia agar dapat bertahan hidup dan menjalani hidupnya dengan tenang, yang keanekaragamannya tergantung pada pendapatan tiap individunya (Baidhowi:2014).

Mata pencaharian hidup adalah suatu usaha atau kerja ekonomi yang bertujuan untuk memperoleh kebutuhan hidup sehari-hari atau untuk memperoleh bahan kehidupan untuk jangka waktu tertentu. Keanekaragaman jumlah pendapatan tiap individu, bergantung dari tiap-tiap mata pencaharian individu. Keanekaragaman mata pencaharian, khususnya di Indonesia di karenakan Indonesia memiliki beragam kekayaan hayati dan sumber daya manusia. Indonesia cocok dalam bidang pembangunan pertanian yang tidak banyak dimiliki oleh Negara lain (Sukino, 2013:6).

Aktifitas dan kebutuhan manusia tersebut berkaitan dengan tiga aspek dalam ekonomi yaitu produksi, konsumsi, dan distribusi.Konsumsi merupakan bagian yang tidak terpisahkan dari perilaku manusia dalam memenuhi kebutuhan hidup yaitu sandang, pangan, dan papan (Suwiknyo, 2010:148). Konsumsi secara umum didefinisikan sebagai penggunaan barang dan jasa yang secara langsung 
Arfiliananda, et al/Jurnal Ekonomi Syariah Teori dan Terapan Vol.5 No.8 Agustus 2018: 620-

\section{0; RASIONALITAS KONSUMSI PETAN PROBOLINGGO DALAM PERSPEKTIF ISLAM}

akan memenuhi kebutuhan hidup manusia. Untuk dapat mengkonsumsi, seseorang harus memiliki pendapatan. Besar kecilnya pendapatan seseorang sangat menentukan tingkat konsumsinya.

Pada perspektif rasionalitas konsumsi Islam, ketika rasionalitas konsumsi seseorang tinggi, maka keputusan seseorang untuk membeli barang yang merupakan keinginan cenderung menurun, karena orang tersebut berpikiran rasional sehingga akan memenuhi kebutuhannya terlebih dahulu daripada keinginan. Muhammad (2004:152) mengatakan kebutuhan manusia dibagi menjadi tiga tingkatan yaitu: dharuriyyat (primer), hajjiyat (sekunder), dan tahsiniyyat (pelengkap). Kebutuhan dharuriyyat mencakup: agama (din), kehidupan (nafs), pendidikan ('aql), keturunan (nasl), dan harta (mal).

Secara umum presentase pengeluaran untuk makanan masih mendominasi pola pengeluaran di Indonesia, meskipun masih berada proporsi sekitar 60\%. Tahun 2013, secara nasional presentase pengeluaran rumah tangga pertanian untuk makanan adalah sebesar58,78\%(pusdatin.setjen.pertanian.g o.id). Dari data tersebut terlihat bahwa petani pada umumnya lebih mementingkan pengeluaran untuk makanan daripada non makanan, namun hal ini berbeda dengan fenomena yang ada di Desa Sumber, Probolinggo dimana pada saat peneliti melakukan pra riset mendapatkan informasi dari kepala desa
MUSLIM PADA DESA SUMBER KABUPATEN setempat bahwa penduduknya yang mayoritas adalah petani kentang muslim yang mayoritas sukses tetapi tidak terlalu memperhatikan pendidikan dan kualitas kesehatannya. Peneliti juga menemukan pada saat pra riset ada beberapa petani di daerah tersebut menggunakan pendapatan panennya untuk membeli barang mewah seperti mobil Pajero atau motor Ninja yang harganya diatas harga barang yang tidak semua masyarakat bisa membelinya. Bahkan menurut kepala desa setempat ada juga penduduk yang ketika mendapatkan hasil panen uangnya digunakan berfoya-foya untuk tradisi desa yang terkadang dilakukan hanya karena gengsi, bukan karena kebutuhannya. Hal ini menurut peneliti tidak sesuai dengan prinsip konsumsi dalam Islam, karena Islam memiliki prinsip kesederhanaan dalam berkonsumsi, seperti yang tercantum dalam Al-Qur'an surat Al-Furqan ayat 67:

"Dan orang-orang yang apabila membelanjakan (harta), mereka tidak berlebihan, dan tidak (pula) kikir, dan adalah (pembelanjaan itu) di tengahtengah antara yang demikian." (QS. AlFurqan:67).

Ada juga beberapa penduduk yang bisa membeli mobil mewah namun tidak memiliki MCK (Mandi Cuci Kakus) dirumahnya. Rata-rata penduduk di desa tersebut juga membuang sampah sembarangan, sampah-sampah hanya dibuang begitu saja dibelakang rumah dan dibiarkan mengalir kebawah jika terkena hujan.. Fenomena diatas menginspirasi penulis untuk meneliti 
Arfiliananda, et al/Jurnal Ekonomi Syariah Teori dan Terapan Vol.5 No.8 Agustus 2018: 620630; RASIONALITAS KONSUMSI PETANI MUSLIM PADA DESA SUMBER KABUPATEN PROBOLINGGO DALAM PERSPEKTIF ISLAM

apakah petani di Desa Sumber membeli barang mewah (tahsiniyyat) setelah kebutuhan pokok (dharuriyyat) mereka telah terpenuhi terlebih dahulu. Mahasiswa yangmemiliki pengetahuan tentang konsumsi Islam, tentu memahami bahwa tuntunan Islam dalam berkonsumsi harus didasari dengan motivasi untuk mencapai maslahah bukan maksimalisasi utilitas (Halim:2014).

Berdasar latar belakang masalah diatas, maka penulis tertarik menulis sebuah penelitian dengan judul

Rasionalitas Konsumsi Petani Muslim pada Desa Sumber Kabupaten Probolinggo dalam Perspektif Islam.

\subsection{Rumusan Masalah}

Berdasarkan latar belakang tersebut, maka rumusan masalah dalam penelitian ini adalah: Bagaimana Rasionalitas Konsumsi Petani Muslim pada Desa Sumber Kabupaten Probolinggo dalam Perspektif Islam?

\subsection{Tujuan Penelitian}

Sesuai dengan rumusan masalah diatas, maka tujuan penelitian yang hendak dicapai dalam penelitian ini adalah untuk mengetahui Rasionalitas Konsumsi Petani Muslim pada Desa Sumber Kabupaten Probolinggo dalam Perspektif Islam.

\section{LANDASAN TEORI}

Rasionalitas Konsumsi dalam Perspektif Ekonomi Konvensional

Dagun (1992:2) menyatakan konsep rasional dalam manusia ekonomi adalah kegiatan ekonomi sebagai kegiatan masuk akal, kegiatan ekonomi adalah menjadikan istilah-istilah ekonomi masuk akal. Suyanto (2013:109) menulis teori Adam Smith yang menyatakan bahwa masyarakat yang kapitalistik dan rasional umumnya baru membeli dan mengkonsumsi sesuatu ketika mereka membutuhkan, dan itu pun dengan dasar pertimbangan yang serba rasional. Mengalkulasi untung rugi dan dibayangkan masyarakat senantiasa mencari komoditas dengan harga terendah karena disitulah sifat rasional masyarakat bekerja.

\section{Konsep Rasionalitas Konsumsi Islam}

Menurut Logati (2011) terminologi rasionalitas merupakan terminologi yang sangat longgar. Argumentasi apa pun yang dibangun, selama hal itu memenuhi kaidah-kaidah logika yang ada, dan oleh karenanya dapat diterima dengan akal, maka hal ini dapat dianggap sebagai bagian dari ekspresi rasionalitas. Oleh sebab itu, terminologi yang dibangun atas kaidah-kaidah yang diterima secara universal dan tidak perlu dilakukan pengujian untuk membuktikan kebenarannya sebagai aksioma.

Aksioma-aksioma ini akan diposisikan sebagai acuan dalam pengujian rasionalitas dari suatu argumen atau perilaku. Konsumsi dalam Islam tidak hanya merupakan fungsi dari pendapatan dan utility saja, sedangkan tujuannya pun bukan semata-mata hanya memaksimalkan 
Arfiliananda, et al/Jurnal Ekonomi Syariah Teori dan Terapan Vol.5 No.8 Agustus 2018: 620-

630; RASIONALITAS KONSUMSI PETANI PROBOLINGGO DALAM PERSPEKTIF ISLAM

kepuasan saja, seperti yang selama ini dikenal didalam teori ekonomi sekuler mengenai perilaku konsumsi.

\section{Preferensi Konsumsi dalam Islam}

Tujuan Konsumsi dalam Islam adalah memperoleh maslahah di dunia dan akhirat, seperti yang tercantum dalam surat Al-Qashash ayat 27:

"Dan carilah pada apa yang telah dianugerahkan Allah kepadamu (kebahagiaan) negeri akhirat, dan janganlah kamu melupakan bahagianmu dari (kenikmatan) duniawi dan berbuat baiklah (kepada orang lain) sebagaimana Allah telah berbuat baik, kepadamu, dan janganlah kamu berbuat kerusakan di (muka) bumi. Sesungguhnya Allah tidak menyukai orang-orang yang berbuat kerusakan."

Ayat diatas menjelaskan bahwa Allah telah berfirman agar konsumsi di dunia dan akhirat haruslah seimbang. Perilaku konsumsi Islami mengajarkan manusia agar mengkonsumsi pendapatan atau harta agar selalu seimbang untuk di akhirat maupun di dunia dengan menggunakan harta yang didapat untuk berbuat kebaikan dengan sesama manusia atau makhluk hidup lainnya di muka bumi. Konsumsi akhirat dalam hal ini yang dimaksud adalah konsumsi yang ditujukan untuk beribadah kepada Allah SWT. Beribadah dalam hal ini yaitu zakat, infaq, shadaqah, waqaf, haji, dan amal ibadah. Tentu hal ini berbeda dengan konsumsi non Islam yang menghabiskan seluruh pendapatannya $100 \%$ untuk konsumsi dunia saja.
MUSLIM PADA DESA SUMBER KABUPATEN Anto (2003) dalam Huda (2006) menjelaskan bahwa preferensi konsumsi dalam Islam dan pemenuhannya dapat dipetakan sebagai berikut:

Utamakan Akhirat daripada Dunia Pada tataran dasar konsumsi dilakukan bersifat duniawi (CW) dan bersifat Ibadah (Ci). Yang dimana keduanya bukan substitusi yang sempurna dikarenakan perbedaan nilai ekstrim. Ibadah lebih bernilai tinggi karena orientasinya pada meraih falah yaitu pahala dari Allah SWT.

Konsisten dalam Pemenuhannya Ulama telah membagi prioritas pemenuhan kebutuhan kedalam tiga bagian:

a. Dharuriyyah, yaitu kebutuhan tingkat dasar atau kebutuhan primer

b. Hajjiyah, yaitu kebutuhan pelengkap atau sekunder

c. Tahsiniyyah, yaitu kebutuhan mewah atau tersier.

Memperhatikan Etika dan Norma Islam memiliki etika dan norma dalam berkonsumsi. Diantaranya: kesederhanaan, keadilan, kebersihan, halalan toyyiban, keseimbangan, dan lain-lain.

\section{Kajian tentang Mata Pencaharian Penduduk Desa}

Mata pencaharian hidup adalah suatu usaha atau kerja ekonomi yang 
Arfiliananda, et al/Jurnal Ekonomi Syariah Teori dan Terapan Vol.5 No.8 Agustus 2018: 620-

630; RASIONALITAS KONSUMSI PETANI PROBOLINGGO DALAM PERSPEKTIF ISLAM

bertujuan untuk memperoleh kebutuhan hidup sehari-hari atau untuk memperoleh bahan kehidupan untuk jangka waktu tertentu. Sistem mata pencaharian hidup merupakan produk dari manusia sebagai homo economicus menjadikan tingkat kehidupan manusia secara umum meningkat. Kehidupan manusia pada tingkat food gathering memang sama dengan binatang, tetapi dalam tingkatan food producing terjadi kemajuan yang sangat pesat karena pada tingkat ini manusia telah mengenal bercocok tanam, beternak, mengusahakan kerajinan dan lain-lain

\section{METODE PENELITIAN}

\section{Pendekatan Penelitian}

Berdasarkan rumusan masalah yang telah ditetapkan sebelumnya yaitu bagaimana rasionalitas konsumsi petani muslim pada desa Sumber Kabupaten Probolinggo, maka peneliti menetapkan metode penelitian yang digunakan untuk penelitian ini adalah dengan pendekatan kualitatif. Hal ini dikarenakan rumusan masalah tersebut tidak dapat diperoleh dengan menggunakan perhitungan data dalam menemukan

jawaban. Pengumpulan data dan informasi akan dilakukan melalui teknik wawancara dan observasi terhadap sumber-sumber data yang diperlukan. Menurut Bogdan dan Taylor dalam Moleong (2014:3), pendekatan kualitatif adalah prosedur penelitian yang menghasilkan data deskriptif berupa kata-kata tertulis atau
MUSLIM PADA DESA SUMBER KABUPATEN lisan dari orang-orang dan perilaku yang dapat diamati.

\section{Ruang Lingkup Penelitian}

Penelitian yang dimaksud adalah dalam menjawab rumusan masalah penelitian yaitu "Bagaimana rasionalitas konsumsi petani muslim pada desa Sumber Kabupaten Probolinggo dalam perspektif Islam?". Rumusan masalah tersebut menjadi acuan dalam menentukan ruang lingkup penelitian ini. Ruang lingkup penelitian ini terbatas hanya pada alasan bagaimana rasionalitas konsumsi petani muslim pada desa Sumber Kabupaten Probolinggo dalam perspektif Islam.

Ruang lingkup dalam penelitian ini adalah rasionalitas konsumsi dalam perspektif Islam yang dilihat dari preferensi konsumsi dalam Islam. Subjek yang diteliti dalam penelitian ini adalah petani muslim yang memiliki lahan pertanian sendiri dan objek penelitian ini adalah Desa Sumber Kabupaten Probolinggo.

\subsection{Unit Analisis}

Unit analisis digunakan untuk menyeleksi siapa saja yang akan dijadikan sebagai informan dari penelitian yang akan dilakukan. Individu yang akan peneliti jadikan sebagai informan dalam penelitian ini adalah petani muslim pada desa Sumber Kabupaten Probolinggo yang memiliki rumah dan lahan pertanian, dikarenakan menurut peneliti dengan harta yang dimiliki tersebut petani dianggap sudah mencapai kesejahteraan dan bisa diukur apakah dalam mengkonsumsi suatu barang, petani 
Arfiliananda, et al/Jurnal Ekonomi Syariah Teori dan Terapan Vol.5 No.8 Agustus 2018: 620-

630; RASIONALITAS KONSUMSI PETANI PROBOLINGGO DALAM PERSPEKTIF ISLAM

tersebut sesuai dengan rasionalitas konsumsi dalam Islam atau tidak.

\subsubsection{Teknik Pengambilan Informan}

Penelitian ini menggunakan teknik purposive sampling dalam mendapatkan informan. Menurut Sugiyono (2012:218) purposive sampling adalah teknik pengambilan sampel sumber data dengan pertimbangan tertentu. Pertimbangan ini misalnya memahami informasi sehingga akan memudahkan peneliti untuk menjelajahi obyek atau situasi sosial yang diteliti.

Dalam penelitian ini diambil informan yang merupakan petani muslim di Desa Sumber Kabupaten Probolinggo. Untuk memperoleh informan ditetapkan beberapa kriteria yang penerapannya bersifat purposive sampling yaitu sebagai berikut:

1. Petani muslim di Desa Sumber Kabupaten Probolinggo.

2. Petani muslim di Desa Sumber Kabupaten Probolinggo yang memiliki rumah dan lahan pertanian sendiri.

\subsection{Teknik Pengumpulan Data}

Proses pengumpulan data merupakan salah satu bagian penting dalam penelitian. Tanpa mengetahui teknik pengumpulan data yang tepat peneliti tidak akan dapat memperoleh data penelitian.Penelitian ini membutuhkan dua jenis data yaitu data primer dan data sekunder. Data primer diperoleh dengan menggunakan prosedur sebagai berikut :

a. Persiapan awal
MUSLIM PADA DESA SUMBER KABUPATEN

Pada tahap ini, peneliti telah menghubungi informan yang merupakan petani muslim pada desa Sumber Kabupaten Probolinggo.

b. Saat di lokasi penelitian

Peneliti menjelaskan maksud dan tujuan penelitian kepada informan bahwa peneliti akan melakukan penelitian tentang bagaimana rasionalitas konsumsi petani muslim pada desa Sumber Kabupaten Probolinggo dalam perspektif Islam. Peneliti juga menanyakan tentang bagaimana kehidupan sehariharinya, pekerjaan, keluarga, apa saja kebutuhannya, dan lain-lain, selain itu peneliti juga melakukan wawancara secara mendalam dan terbuka kepada petani tersebut. Kegiatan ini dilakukan sampai peneliti mendapatkan jawaban dari rumusan masalah yang telah dibuat sebelumnya.

c. Pengumpulan data

Peneliti mendapatkan data dari hasil wawancara dengan petani muslim yang menjadi subyek penelitian. Wawancara dilakukan secara terbuka dengan pertanyaan yang terus berkembang tetapi tetap terfokus dan mengarah pada topik penelitian. Hasil wawancara akan didokumentasikan sendiri oleh peneliti.

Untuk data sekunder diperoleh dari literatur yang berisi tentang rasionalitas konsumsi dalam perspektif Islam yang diperoleh dengan cara 
Arfiliananda, et al/Jurnal Ekonomi Syariah Teori dan Terapan Vol.5 No.8 Agustus 2018: 620-

630; RASIONALITAS KONSUMSI PETANI PROBOLINGGO DALAM PERSPEKTIF ISLAM

membaca buku, jurnal, dan buku di internet.

\subsection{Teknik Keabsahan Data}

Moleong (2014:320) mengatakan, yang dimaksud dengan keabsahan data adalah setiap keadaan harus mendemonstrasikan nilai yang benar, menyediakan dasar agar hal itu dapat diterapkan dan memperbolehkan keputusan luar yang dapat dibuat tentang konsistensi dari prosedurnya. Untuk menetapkan keabsahan data diperlukannya sebuah pemeriksaan yang berdasarkan kriteria kepercayaan, keteralihan, kebergantungan dan kepastian.

Penelitian ini menggunakan duateknik keabsahan data, yaitu teknik ketekunan/keajegan pengamatandan teknik triangulasi data. Ketekunan pengamatan yaitu menemukan ciri-ciri dan unsur-unsur dalam situasi yang sangat relevan dengan persoalan atau isu yang sedang dicari dan kemudian memusatkan diri pada hal-hal tersebut secara rinci (Moleong, 2014:329), pada teknik ketekunan pengamatan, peneliti melakukan penelitian dengan wawancara secara rinci, mendalam, dan teliti kepada responden.

\subsection{Teknik Analisis}

Analisis data kualitatif menurut Bogdan dan Biklen dalam Moleong (2014:248) adalah upaya yang dilakukan dengan jalan bekerja dengan data, mengorganisasikan data, memilah menjadi satuan yang dapat dikelola, mensintesiskannya, mencari dan
MUSLIM PADA DESA SUMBER KABUPATEN menemukan pola, menemukan apa yang penting dan apa yang dipelajari, dan memutuskan apa yang dapat diceritakan pada orang lain.

Penelitian ini berusaha untuk mendeskripsikan bagaimana rasionalitas konsumsi petani muslim pada desa Sumber Kabupaten Probolinggo dalam perspektif Islam. Hasil wawancara akan dideskripsikan agar dapat memberikan gambaran secara utuh, mendalam dan transparan.

\section{Hasil dan Pembahasan}

Berdasarkan penelitian yang telah dilakukan di lapangan dan ruang lingkup yang digunakan dalam penelitian ini, maka hasil penelitian hanya akan membahas mengenai Rasionalitas Konsumsi Petani muslim pada desa Sumber Kabupaten Probolinggo dalam perspektif Islam, yang kemudian dari hasil penelitian tersebut akan disesuaikan dengan teori Rasionalitas Konsumsi dalam Perspektif Islam.

1. Utamakan Akhirat daripada Dunia Wujud mengutamakan akhirat daripada dunia para petani muslim pada desa Sumber Kabupaten Probolinggo diwujudkan dengan sikap mengutamakan sedekah untuk anak yatim atau zakat daripada kepentingan dunia seperti membeli mobil. Zakat tersebut mereka lakukan sebagai bentuk rasa syukur atas rezeki yang telah didapatkan dan karena merasa bahwa dari harta yang mereka dapatkan terdapat rezeki 
Arfiliananda, et al/Jurnal Ekonomi Syariah Teori dan Terapan Vol.5 No.8 Agustus 2018: 620-

630; RASIONALITAS KONSUMSI PETANI PROBOLINGGO DALAM PERSPEKTIF ISLAM

orang lain, bahkan ada sebagian yang memiliki rezeki lebih sudah menunaikan Ibadah haji. Zakat, Infaq, Shadaqah, dan Haji merupakan konsumsi yang bertujuan untuk kebahagiaan akhirat.

Informan selalu menyisihkan pendapatan panennya untuk zakat, infaq, dan sedekah karena merasa dalam rezeki yang mereka peroleh tersebut terdapat hak orang lain. Melakukan zakat menurut informan penting karena dapat membantu sesama dan hal ini merupakan tabungan untuk kehidupan di masa yang akan datang.

2. Konsistensi dalam Pemenuhannya Wujud konsisten pemenuhan kebutuhannya diwujudkan oleh petani muslim pada desa Sumber Kabupaten Probolinggo dengan mengutamakan kebutuhan pokok terlebih dahulu. Setelah kebutuhan pokok (dharuriyyat) terpenuhi baru memenuhi kebutuhan yang lain seperti sekunder (hajjiyat) dan tersier (tahsiniyat). Untuk pemenuhan kebutuhan tersier (tahsiniyat), informan meninjau dulu dari segi manfaat dan kepentingannya.

Informan cenderung memenuhi kebutuhan dharuriyyat atau kebutuhan primer terlebih dahulu, sedangkan untuk kebutuhan hajiyyat dan tahsiniyyat dilihat dulu dari manfaat dan kepentingannya. Informan mengkonsumsi kebutuhan hajiyyat (sekunder) dan tahsiniyyat
MUSLIM PADA DESA SUMBER KABUPATEN (tersier) hanya ketika memiliki rejeki berlebih dan kebutuhan tersebut dirasa perlu untuk dipenuhi.

Informan juga menyadari akan pentingnya berzakat, infaq, sedekah dan haji yang merupakan salah satu Ibadah dalam Islam. Zakat, infaq, dan sedekah dirasa penting juga karena rata-rata petani muslim pada desa Sumber Kabupaten Probolinggo lebih suka menggunakan pendapatannya untuk membantu sesama dibandingkan untuk mengkonsumsi barang-barang yang kurang dibutuhkan, oleh karena itu informan akan mengkonsumsi kebutuhan tersier seperti mobil hanya ketika mereka membutuhkannya.

3. Memperhatikan Etika dan Norma

\section{Kesederhanaan}

Wujud kesederhanaan dalam berkonsumsi ditunjukkan oleh para petani muslim pada desa sumber Kabupaten Probolinggo dengan hidup apa adanya. Mereka cenderung mengutamakan kebutuhan daripada keinginan. Para informan menyatakan bahwa tidak boros itu adalah ketika pendapatan mereka digunakan untuk hal yang bermanfaat, bukan konsumsi yang hanya menuruti keinginan atau nafsu saja seperti membeli barang meskipun tidak membutuhkannya.

Informan juga menyatakan bahwa kebutuhan pokok harus diutamakan agar bisa memenuhi kebutuhan yang selanjutnya. Mereka menyisihkan 
Arfiliananda, et al/Jurnal Ekonomi Syariah Teori dan Terapan Vol.5 No.8 Agustus 2018: 620-

630; RASIONALITAS KONSUMSI PETANI PROBOLINGGO DALAM PERSPEKTIF ISLAM

pendapatan panennya yang kemudian akan diinvestasikan menjadi lahan pertanian, hewan ternak, atau dibelikan barang yang bisa dijual kembali ketika hasil pertaniannya menurun.

\section{Keadilan}

Wujud keadilan ditunjukkan oleh petani muslim pada desa Sumber Kabupaten Probolinggo dengan bekerja sebagai petani yang menjunjung tinggi kejujuran. Informan bertani dengan jujur, tidak curang yang dapat merugikan orang lain, selain itu para petani muslim pada desa Sumber Kabupaten Probolinggo mengolah pertanian dengan cara yang halal. Menurut para informan, dengan mencari rezeki dijalan yang benar maka kita akan mendapat berkah dari Allah SWT.

\section{Kebersihan}

Wujud menjaga kebersihan dalam berkonsumsi diwujudkan oleh petani muslim pada desa sumber Kabupaten Probolinggo dengan mencuci terlebih dahulu makanan yang akan mereka masak, selain itu informan menutup minuman yang dihidangkan untuk tamu agar lalat tidak masuk didalamnya karena lalat yang masuk kedalam makanan atau minuman dapat membawa bakteri atau kuman yang dapat mengganggu kesehatan.

Informan mengatakan bahwa kebersihan sangatlah penting untuk dijaga, terutama kebersihan
MUSLIM PADA DESA SUMBER KABUPATEN makanan dan minuman yang dikonsumsi. Pentingnya kebersihan dalam mengkonsumsi makanan dan minuman adalah karena kedua barang tersebut dicerna dan masuk kedalam tubuh, tentu hal ini dapat mempengaruhi kesehatan dari orang yang mengkonsumsi makanan atau minuman tersebut. Informan juga mengetahui tentang hadits Islam tentang kebersihan yaitu:

Annaẓafatun minal-īmān

"Kebersihan itu sebagian dari iman." (HR. Ahmad)

\section{Halalan toyyiban}

Wujud keseimbangan dalam berkonsumsi ditunjukkan oleh para petani di Desa Sumber Kabupaten Probolinggo dengan membagi pendapatan yang diperoleh dari hasil panen untuk beribadah dan konsumsi duniawi. Informan juga mengatakan bahwa kebutuhan dunia dan akhirat harus seimbang, sehingga mereka mengutamakan kebutuhan akhirat seperti zakat, sedekah, infag maupun haji setelah kebutuhan pokok terpenuhi dibandingkan mengkonsumsi kebutuhan tahsiniyyat (tersier).

\section{SIMPULAN}

Berdasarkan pada hasil pembahasan dalam bab empat, maka simpulan dari penelitian ini Rasionalitas Konsumsi Petani muslim pada desa Sumber Kabupaten Probolinggo dalam Perspektif Islam adalah sebagai berikut: 
Arfiliananda, et al/Jurnal Ekonomi Syariah Teori dan Terapan Vol.5 No.8 Agustus 2018: 620-

630; RASIONALITAS KONSUMSI PETANI PROBOLINGGO DALAM PERSPEKTIF ISLAM

1. Mengutamakan akhirat daripada dunia dengan mengutamakan zakat, infaq, shadaqah, dan haji yang merupakan ibadah kepada Allah SWT dibandingkan membeli kebutuhan tersier duniawi seperti membeli mobil maupun membeli barang-barang lain yang bukan merupakan kebutuhan namun hanya keinginan atau menuruti hawa nafsu saja tanpa ada manfaat dan kepentingannya. Semakin besar konsumsi ibadah, maka semakin besar menuju falah, karena seorang muslim yang rasional yaitu yang beriman. Seorang muslim yang beriman adalah yang anggaran ibadahnya lebih banyak dibandingkan anggaran konsumsi duniawinya yang akan menjauhkan dari falah.

2. Konsisten dalam pemenuhan kebutuhannya dengan mengutamakan kebutuhan pokok (dharuriyyat) terlebih dahulu dibanding kebutuhan lainnya. Untuk kebutuhan hajjiyat (sekunder) dan tahsiniyyat (tersier) dipenuhi hanya ketika dirasa perlu untuk dipenuhi dan terdapat manfaat atas pemenuhannya.

3. Memperhatikan etika dan norma yang terdiri dari hidup sederhana tidak berlebih-lebihan atau boros, menjaga keadilan dengan bekerja dengan jujur sebagai petani yang tidak merugikan orang lain baik pembeli maupun sesama petani yang lainnya, menjaga kebersihan
MUSLIM PADA DESA SUMBER KABUPATEN

berkonsumsi dengan menutup makanan dan minuman agar terhindar dari lalat yang dapat mengganggu kesehatan, memperhatikan halalan toyyiban dengan bertani secara halal yaitu bekerja dengan jujur maupun menggunakan hasil pendapatan panen untuk konsumsi yang benar, tidak digunakan untuk foya-foya dan judi namun digunakan untuk berzakat, sedekah, dan memperhatikan keseimbangan dalam berkonsumsi antara konsumsi dunia dengan akhirat agar mendapat berkah dari Allah SWT.

4. Dari ketiga simpulan diatas, maka dapat disimpulkan bahwa Rasionalitas Konsumsi Petani Muslim di Desa Sumber Kabupaten Probolinggo telah sesuai dengan preferensi konsumsi dalam perspektif Islam. Ketika preferensi seseorang tersebut benar, maka dapat dikatakan seseorang tersebut rasional.

Saran yang dapat penulis sampaikan dalam penelitian ini adalah:

1. Sebagai umat Muslim, sudah seharusnya kita berkonsumsi dengan benar sesuai ajaran yang telah tercantum dalam Al-Qur'an dan Hadits. Hasil penelitian ini menunjukkan bahwa penerapan rasionalitas konsumsi dalam perspektif Islam akan membuat seseorang menjadi konsumen yang lebih memperhatikan pola konsumsi yang 
Arfiliananda, et al/Jurnal Ekonomi Syariah Teori dan Terapan Vol.5 No.8 Agustus 2018: 620-

630; RASIONALITAS KONSUMSI PETANI PROBOLINGGO DALAM PERSPEKTIF ISLAM

benar menurut Islam dalam kegiatan konsumsi sehari-hari, karena konsumsi dunia dan akhirat harus seimbang.

2. Bagi peneliti selanjutnya diharapkan dapat meneliti topik yang sama dengan penelitian yang lebih mendalam mengenai kajian dengan tema rasionalitas konsumsi petani muslim pada desa sumber Kabupaten Probolinggo dengan subjek maupun objek yang berbeda, sehingga bisa didapatkan penelitian yang lebih komprehensif.

\section{DAFTAR PUSTAKA}

Anto, Hendrie MB. 2003. Pengantar

Ekonomika Mikro Islami.

Yogyakarta:EKONISIA.

Baidhowi, Bagus. 2014. Implementasi

Konsumsi Islam pada Pengajar

Pondok Pesantren . Universitas

Airlangga Surabaya.

Dagun, Save M. 1992. Pengantar Filsafat

Ekonomi. Jakarta:Rineka Cipta.

Halim, Abdul. 2014. Analisis Komparatif

terhadap Konsep Konsumsi dalam

Pandangan Ekonomi Islam dan

Ekonomi Konvensional. Jakarta.

Huda, Nurul. 2006. Konsep Perilaku

Konsumsi dalam Ekonomi Islami. ISSN.

Logati, Anggraini. 2011 . Rasionalitas

Konsumsi Keluarga Muslim Beranak

Banyak Perspektif Maqashid Syariah.

Universitas Airlangga Surabaya.

Moleong, Lexy J. 2014. Metodologi

Penelitian Kualitatif. Edisi Revisi.

Bandung:Remaja Rosdakarya.
MUSLIM PADA DESA SUMBER KABUPATEN

Muhammad. 2004. Ekonomi Mikro dalam Perspektif Islam.Yogyakarta:BPFE-

Yogyakarta.

Pusat Data dan Sistem Informasi

Pertanian.2014. Analisis Data

Kesejahteraan Petani 2014, (online),

(http://pusdatin.setjen.pertanian.go.id

/tinymcpuk/gambar/file/Analisis_Kesta

n_2014.pdf, diakses 11 Januari 2017).

Suwiknyo, Dwi. 2010. Kompilasi Tafsir Ayat-

ayat Ekonomi Islam.

Yogyakarta:Pustaka Pelajar.

Sukino. 2013. Membangun Pertanian

dengan Pemberdayaan Masyarakat

Tani (terobosan menanggulangi

kemiskinan). Yogyakarta:Pustaka Baru

Press.

Suyanto, Bagong. 2013. Sosiologi Ekonomi. Jakarta:Kencana 